\title{
Animal Husbandry Practices in Hill Farming Situation: Gender Role Analysis
}

\author{
Rakesh Roy $^{1 *}$, Tista Mondal ${ }^{2}$ and M. W. Moktan ${ }^{1}$ \\ ${ }^{1}$ Krishi Vigyan Kendra, Uttar Banga Krishi Viswavidyalaya, Kalimpong-734301, Darjeeling, \\ West Bengal, India \\ ${ }^{2}$ Poultry Multiplication Centre, Animal Resources Development Department, GTA, \\ Kalimpong-734301, Darjeeling, West Bengal, India \\ *Corresponding author
}

\section{Keywords}

Feeding, Gender, Hill farming situation, Livestock farming, Marketing

Article Info

Accepted:

24 May 2018

Available Online:

10 June 2018

\section{A B S T R A C T}

Agriculture in general and livestock in particular are important to make women empowered by giving them employment. Research and experience confirm the importance of gender equity, not only as a fundamental human right, but also as essential to poverty reduction and improved living standard. The study was purposively conducted with an objective to assess gender role in animal husbandry practices in hill farming situation where involvement of the women in agriculture is higher than their counterpart. Data collection was done through personal interview from randomly selected 60 farm families. Both male and female members of the family were interviewed separately. Thus, forms a sample size of 120 respondents for the study. The study shows that women were highly involved in major animal husbandry practices such as breeding, feeding, management and animal healthcare practices. Mann Whitney $U$ test shows highly significant difference in between men and women farmers in respect to involvement in major animal husbandry practices. The study further reveals that women role in economic activities like making decision to buying or selling and keeping money were considerably less compared to men in animal husbandry practices. Mann Whitney $U$ test shows highly significant difference between men and women in relation to livestock marketing practices. Policy makers as well as the extension agencies working in hill region should focus more on women for dissemination of recent livestock technologies to enhance the production performance of animal husbandry sector in hill farming situation.

\section{Introduction}

As per 2011 census, women workforce in agriculture and allied sectors is 98 million, which is 37 per cent of total wage workers. Research on women in agriculture shows that on an average women work for 15 to 16 hours a day and 4 to 5 hours more than their men counterparts (Singh et al., 2016). Agriculture in general and livestock in particular are important to make women empowered by giving them employment. India's livestock sector is one of the largest in the world. It has $56.7 \%$ of world's buffaloes, $12.5 \%$ cattle, $20.4 \%$ small ruminants, $2.4 \%$ camel, $1.4 \%$ equine, $1.5 \%$ pigs and $3.1 \%$ poultry. In $2010-$ 
2011, livestock generated outputs worth Rs. 2075 billion (at 2004-05 prices) which comprised $4 \%$ of Gross Domestic Product (GDP) and $26 \%$ of the agricultural GDP (GoI, 2012).

Out of 600 million rural poor of the world who keep livestock two third are women (FAO, 2012). In India also, livestock production is largely in the hands of women. Women constitute about 69\% of workforce engaged in livestock sector (Patel et al., 2016). Most of the animal farming activities such as fodder collection, feeding, watering, and health care, management, milking and household-level processing, value addition and marketing are performed by women. Despite their considerable involvement and contribution, significant gender inequalities also exist in access to technologies, credit, information, inputs and services probably because of inequities in ownership of productive assets including land and livestock.

Livestock are the asset which can be easily owed by women and which have the potential to make contribution towards reduction in gender asset gap with in household (Kristjanson et al., 2010) and livestock often is the single asset for rural women which is owned and controlled by them and which serves as an important source of income and cash for them during the time of need (World Bank, 2009).

Further, rapidly increasing demand for livestock products creates opportunities for empowerment of women (Taneja, 2013). Gender balanced programs and projects have become an important goal for many public as well as private agencies (Schindler 2008). Therefore, there is a need to correct gender bias in livestock sector, veterinary education, research and service delivery systems as to enhance the effectiveness of women-oriented livestock development programs (GoI, 2012).
Therefore, a study was taken with an objective to assess the role of women in relation to animal husbandry practices in hill farming situation.

\section{Materials and Methods}

\section{Study location}

The study was carried out among livestock farmers located in hills region of West Bengal.

\section{Study design}

The study was designed to assess gender role in animal husbandry activities in hill farming situation. The study was carried out during April 2014 to January 2015. One block each i.e. Darjeeling Pulbazar, Kalimpong II and Mirik was randomly selected from three hill sub-divisions of Darjeeling district and further 2 villages each were randomly selected from these three blocks. From each village, 10 farm families were randomly selected for data collection. Personal interview method through semi structures interview schedule was applied for data collection from both male and female members of the family separately. Thus, 120 respondents form the sample size of the study compounding 60 men and 60 women respondents.

\section{Data analysis}

Data was coded and entered into excel spreadsheets. Descriptive statistics were used to characterize respondents' perceptions. Simple statistical analysis such as percentage was used. Further, non-parametric test like Mann Whitney U Test was performed using SPSS 20.0 software.

\section{Results and Discussion}

The study on gender role in animal husbandry practices were assessed as follows: 
Gender Role in Livestock Breeding Practices

The study shows that livestock breeding practices in hill farming system were done by women farmers. Involvement of women in livestock breeding practices as perceived by both male and female ranged from 27.5 percent to 79.17 percent whereas involvement of men as perceived by both male and female ranged 20.83 percent to 72.5 percent in hill farming system (Table 1). Highest involvement of women was found in taking care and management of pregnant animals whereas men had highest involvement in calling of AI workers or bringing of breeder male. Mann Whitney U test shows highly significant difference between men and women farmers in respect to livestock breeding practices. Artificial insemination related activities were mainly done by male members of the family but taking care and management of the pregnant animals were done by female members of the family (Bishnoi et al., 2014).

\section{Gender Role in Livestock Feeding Practices}

The study reveals that livestock feeding practices in hill farming system were mainly done by women. Involvement of women in livestock feeding practices as perceived by both male and female ranged from 65 percent to 78.83 percent whereas involvement of men as perceived by both male and female was 21.67 percent to 35 percent (Table 2). Highest involvement of women was found in preparation of low cost concentrate feed whereas men had highest involvement in collecting of fodder. Mann Whitney U test shows a highly significant difference between men and women in respect to feeding practices. Cutting of fodder and feeding of feed and fodder to the animals were mainly done by the female members of the family (Singh et al., 2016; Bishnoi et al., 2014 and Poudel et al., 2009).

\section{Gender Role in Livestock Management Practices}

It was found that daily livestock management practices in hill farming situation were mainly done by women. Involvement of women related to livestock management practices as perceived by both male and female ranged from 15.83 percent to 76.67 percent whereas involvement of men as perceived by both male and female was 22.5 percent to 84.17 percent (Table 3).

Table.1 Comparative role analysis in livestock breeding practices as perceived by male and female respondents $(n=120)$

\begin{tabular}{|c|c|c|c|c|c|c|c|}
\hline \multirow[t]{2}{*}{ Activities } & \multicolumn{2}{|c|}{$\begin{array}{c}\text { Perception of } \\
\text { Male (\%) }\end{array}$} & \multicolumn{2}{|c|}{$\begin{array}{l}\text { Perception of } \\
\text { Female }(\%)\end{array}$} & \multicolumn{2}{|c|}{$\begin{array}{c}\text { Overall } \\
\text { perception }(\%)\end{array}$} & \multirow{2}{*}{$\begin{array}{c}\text { Mann } \\
\text { Whitney } \\
\text { U Test } \\
\end{array}$} \\
\hline & Men & Women & Men & Women & Men & Women & \\
\hline Detection of heat & 28.33 & 71.67 & 13.33 & 86.67 & 20.83 & 79.17 & $-9.018^{* *}$ \\
\hline $\begin{array}{l}\text { Calling of AI workers or } \\
\text { bringing of breeder male }\end{array}$ & 80.00 & 20.00 & 65.00 & 35.00 & 72.50 & 27.50 & $-6.957^{* *}$ \\
\hline $\begin{array}{l}\text { Taking care at the time of } \\
\text { mating }\end{array}$ & 76.67 & 23.33 & 60.00 & 40.00 & 68.33 & 31.67 & $-5.669^{* *}$ \\
\hline Taking care after inseminating & 43.33 & 56.67 & 35.00 & 65.00 & 39.17 & 60.83 & $-3.350^{* * *}$ \\
\hline $\begin{array}{l}\text { Care and management of } \\
\text { pregnant animals }\end{array}$ & 18.33 & 81.67 & 8.333 & 91.67 & 13.33 & 86.67 & $-11.337^{* *}$ \\
\hline
\end{tabular}


Table. 2 Comparative role analysis in livestock feeding practices as perceived by male and female respondents $(n=120)$

\begin{tabular}{|c|c|c|c|c|c|c|c|}
\hline \multirow[t]{2}{*}{ Activities } & \multicolumn{2}{|c|}{$\begin{array}{c}\text { Perception of } \\
\text { Male }(\%)\end{array}$} & \multicolumn{2}{|c|}{$\begin{array}{l}\text { Perception of } \\
\text { Female }(\%)\end{array}$} & \multicolumn{2}{|c|}{$\begin{array}{c}\text { Overall } \\
\text { perception }(\%)\end{array}$} & \multirow{2}{*}{$\begin{array}{c}\text { Mann } \\
\text { Whitney } \\
\text { U Test }\end{array}$} \\
\hline & Men & Women & Men & Women & Men & Women & \\
\hline Collecting of fodder & 41.67 & 58.33 & 28.33 & 71.67 & 35.00 & 65.00 & $-4.638^{* *}$ \\
\hline Cutting of fodder & 36.67 & 63.33 & 23.33 & 76.67 & 30.00 & 70.00 & $-6.184^{* *}$ \\
\hline $\begin{array}{l}\text { Feeding of feed and } \\
\text { fodder }\end{array}$ & 36.67 & 63.33 & 21.67 & 78.33 & 29.17 & 70.83 & $-8.503^{* *}$ \\
\hline Feeding of water & 36.67 & 63.33 & 21.67 & 78.33 & 29.17 & 70.83 & $-9.018^{* *}$ \\
\hline $\begin{array}{l}\text { Preparation of low } \\
\text { cost concentrate feed }\end{array}$ & 26.67 & 73.33 & 16.67 & 83.33 & 21.67 & 78.33 & $-8.760^{* *}$ \\
\hline
\end{tabular}

** Significant at $\mathrm{p}<0.01$ level

Table.3 Comparative role analysis in livestock management practices as perceived by male and female respondents $(n=120)$

\begin{tabular}{|c|c|c|c|c|c|c|c|}
\hline \multirow[t]{2}{*}{ Activities } & \multicolumn{2}{|c|}{$\begin{array}{l}\text { Perception of } \\
\text { Male (\%) }\end{array}$} & \multicolumn{2}{|c|}{$\begin{array}{c}\text { Perception of } \\
\text { Female }(\%)\end{array}$} & \multicolumn{2}{|c|}{$\begin{array}{c}\text { Overall } \\
\text { perception }(\%)\end{array}$} & \multirow{2}{*}{$\begin{array}{c}\text { Mann } \\
\text { Whitney } \\
\text { U Test }\end{array}$} \\
\hline & Men & Women & Men & Women & Men & Women & \\
\hline Construction of shed & 86.67 & 13.33 & 81.67 & 18.33 & 84.17 & 15.83 & $-10.564^{* *}$ \\
\hline Cleaning of shed & 31.67 & 68.33 & 15.00 & 85.00 & 23.33 & 76.67 & $-8.245^{* *}$ \\
\hline $\begin{array}{l}\text { Care and management } \\
\text { of new born }\end{array}$ & 25.00 & 75.00 & 20.00 & 80.00 & 22.50 & 77.50 & $-8.503^{* *}$ \\
\hline Milking & 23.33 & 76.67 & 23.33 & 76.67 & 23.33 & 76.67 & $-10.306^{* *}$ \\
\hline Disposal of waste & 31.67 & 68.33 & 20.00 & 80.00 & 25.83 & 74.17 & $-7.472^{* *}$ \\
\hline
\end{tabular}

Table.4 Comparative role analysis in animal healthcare practices as perceived by male and female respondents $(n=120)$

\begin{tabular}{|c|c|c|c|c|c|c|c|}
\hline \multirow[t]{2}{*}{ Activities } & \multicolumn{2}{|c|}{$\begin{array}{l}\text { Perception of } \\
\text { Male (\%) }\end{array}$} & \multicolumn{2}{|c|}{$\begin{array}{l}\text { Perception of } \\
\text { Female (\%) }\end{array}$} & \multicolumn{2}{|c|}{$\begin{array}{c}\text { Overall } \\
\text { perception (\%) }\end{array}$} & \multirow{2}{*}{$\begin{array}{l}\text { Mannn } \\
\text { Whitney } \\
\text { U Test }\end{array}$} \\
\hline & Men & Women & Men & Women & Men & Women & \\
\hline Calling of veterinarian & 26.67 & 73.33 & 40.00 & 60.00 & 33.33 & 66.67 & $-5.153^{* *}$ \\
\hline Providing medicine & 33.33 & 66.67 & 35.00 & 65.00 & 34.17 & 65.83 & $-4.896^{* *}$ \\
\hline Cleaning of wound & 36.67 & 63.33 & 28.33 & 71.67 & 32.50 & 67.50 & $-5.411^{* *}$ \\
\hline $\begin{array}{l}\text { Taking initiative for } \\
\text { vaccination }\end{array}$ & 40.00 & 60.00 & 31.67 & 68.33 & 35.83 & 64.17 & $-4.380^{* *}$ \\
\hline $\begin{array}{l}\text { Care and management } \\
\text { of sick animals }\end{array}$ & 28.33 & 71.67 & 25.00 & 75.00 & 26.67 & 73.33 & $-7.214^{* *}$ \\
\hline Disposal of carcasses & 80.00 & 20.00 & 58.33 & 41.67 & 69.17 & 30.83 & $-5.926 * *$ \\
\hline
\end{tabular}


Table.5 Comparative role analysis in livestock marketing practices as perceived by male and female respondents $(n=120)$

\begin{tabular}{|c|c|c|c|c|c|c|c|}
\hline \multirow[t]{2}{*}{ Activities } & \multicolumn{2}{|c|}{$\begin{array}{l}\text { Perception of } \\
\text { Male }(\%)\end{array}$} & \multicolumn{2}{|c|}{$\begin{array}{l}\text { Perception of } \\
\text { Female }(\%)\end{array}$} & \multicolumn{2}{|c|}{$\begin{array}{c}\text { Overall } \\
\text { perception }(\%)\end{array}$} & \multirow{2}{*}{$\begin{array}{l}\text { Mann } \\
\text { Whitney } \\
\text { U Test }\end{array}$} \\
\hline & Men & Women & Men & Women & Men & Women & \\
\hline $\begin{array}{l}\text { Decision making to buy } \\
\text { or sell animals or animal } \\
\text { products }\end{array}$ & 70.00 & 30.00 & 81.67 & 18.33 & 75.83 & 24.17 & $-7.987^{* *}$ \\
\hline $\begin{array}{l}\text { Marketing of animals or } \\
\text { animal products }\end{array}$ & 70.00 & 30.00 & 73.33 & 26.67 & 71.67 & 28.33 & $-6.699^{* *}$ \\
\hline $\begin{array}{l}\text { Money kept after selling } \\
\text { of animals or animal } \\
\text { products }\end{array}$ & 65.00 & 35.00 & 66.67 & 33.33 & 65.83 & 34.17 & $-4.896^{* *}$ \\
\hline
\end{tabular}

Highest involvement of women was found in taking care and management of new born whereas men had highest involvement in construction of shed. Mann Whitney U test shows highly significant difference between men and women farmers in respect to livestock management practices. Activities like cleaning of shed, care and management of new born and milking were mainly done by female members (Singh et al., 2016; Bishnoi et al., 2014 and Poudel et al., 2009).

\section{Gender Role in Animal Healthcare Practices}

The study shows that animal healthcare practices in hill farming situation were mainly done by women. Involvement of women regarding activities related to animal healthcare practices as perceived by both male and female was ranged from 30.83 percent to 73.33 percent whereas involvement of men as perceived by both male and female was ranged 26.67 percent to 69.17 percent (Table 4). Highest involvement of women was found in taking care and management of sick animals whereas men had highest involvement in disposal of carcasses. Mann Whitney $U$ test shows a highly significant difference between men and women in respect to animal healthcare practices. Engagement of the female member of the family was found higher than male members in animal care (Singh et al., 2016).

\section{Gender Role in Livestock Marketing Practices}

It was found that livestock marketing in hill farming situation were mainly done by men. Involvement of men in livestock marketing practices as perceived by both male and female were ranged from 65.83 percent to 75.83 percent whereas involvement of women as perceived by both male and female ranged from 24.17 percent to 34.17 percent (Table 5). Involvement of men was very high than female in all the aspect of marketing practices.

Only 34.17 percent women kept money after selling of animals or animal products as perceived by both male and female. Mann Whitney $U$ test shows highly significant difference between men and women in respect to marketing practices. Engagement of the male member of the family was found higher than female members in marketing of the produce (Singh et al., 2016 and Poudel et al., 2009). 
The study has shown that female members in the family were more engaged to various animal husbandry practices in hill farming system. Women were more involved in feeding, management and healthcare practices whereas as men were involved in making decision regarding marketing of animals or animal products and keeping the money for future use. Considering this study and similar past studies the policy makers and the extension agencies working in hill region should focus more on women for dissemination of recent livestock technologies to develop animal husbandry in hill farming situation. Extension agencies should also encourage women entrepreneurship through livestock farming in hill farming situation.

\section{References}

Bishnoi R, Singh P, Dubey SK and Sangeetha V. (2014). Gender role in crop and animal husbandry practices and household activities with respect to changing climate in arid ecosystem. Indian Journal of Extension Education, 50(1\&2): 1-3.

FAO (2012). Invisible Guardians: Women Manage Livestock Diversity, FAO, Rome, http://www.fao.org/docrep/016/i3018e/i 3018e00.htm

GoI (2012). Report of the working group on Animal Husbandry and Dairying, $12^{\text {th }}$ five year plan (2012-17). Planning Commission, GoI, New Delhi.
Kristjanson P, Johnson N, Tipilda A, Njuki J, Baltenweck I and Grace D. (2010). Livestock and Women's Livelihoods: A Review of the Recent Evidence, ILRI Discussion Paper No. 20, ILRI, Nairobi.

Patel SJ, Patel MD, Patel JH, Patel, AS and Gelani, RN. (2016). Role of women gender in livestock sector: A review, $J$. Livestock Sci., 7: 92-96

Paudel LN, terMeulen U, Wollny C, Dahal H and Gauly M. (2009). Gender aspects in livestock farming: pertinent issues for sustainable livestock development in Nepal. Livestock Research for Rural Development. Volume 21, Article \#40. Retrieved December 4, 2017, from http://www.lrrd.org/lrrd21/3/paud21040 .htm

Schindler K. (2008). Time allocation, poverty and gender: Evidence from post-war Rwanda. Tropentag, University of Hohenheim, Stuttgart, Germany.

Singh A, Kumbhare NV, Singh P, Sharma N, Patel N and Gurung B. (2016). Gender Analysis of Crop and Animal Husbandry Practices in Hill Agriculture.Indian Journal of Extension Education, 52(3\&4): 53-56

Taneja VK. (2013). Women and livestock. Retrieved on $16^{\text {th }}$ October, 2017 from http://www.dailypost.in/comments/colu mnists/3034-women-andlivestock.

World Bank. (2009). Gender, Agriculture, and Climate Change, Gender in Agriculture, Source Book, 1-28.

\section{How to cite this article:}

Rakesh Roy, Tista Mondal and Moktan M. W. 2018. Animal Husbandry Practices in Hill Farming Situation: Gender Role Analysis. Int.J.Curr.Microbiol.App.Sci. 7(06): 3136-3141. doi: https://doi.org/10.20546/ijcmas.2018.706.368 